\title{
Skrining Aktivitas Antimalaria Beberapa Tanaman Indonesia Hasil Eksplorasi Dari Hutan Raya Cangar, Batu- Malang, Jawa Timur
}

Achmad Fuad Hafid ${ }^{l, 2 *}$, Nike Puliansari ${ }^{1}$, Nur Suci Lestari ${ }^{1}$, Lidya Tumewu ${ }^{2}$, Abdul Rahman ${ }^{1,2}$, Aty Widyawaruyanti ${ }^{1,2}$ ${ }^{1}$ Departemen Farmakognosi dan Fitokimia, Fakultas Farmasi, Kampus B Universitas Airlangga, Surabaya 60286

${ }^{2}$ Center for Natural Product Medicine Research and Development, Lembaga Penyakit Tropis, Kampus C

Universitas Airlangga, Surabaya 60115

*Corresponding author: achmadfuad@ff.unair.ac.id; achmadfuad@yahoo.com

\begin{abstract}
Background: Malaria is the most important parasitic disease. Malaria control which depends on specific chemotherapy now complicated by resistance of Plasmodium falciparum to most commonly available antimalarial drug. Such situation has heralded the need for alternative antimalarial therapy. Objective: This research aim was to find new antimalarial candidates from some Indonesia plants collected from Cangar National Forest, Batu-Malang, East Java. Methods: Eleven samples of leaves and stem extracts were screened against Plasmodium falciparum 3D7 culture which maintained in RPMI-1640 Medium. Samples tested in concentration of 0.01, 0.1, 1,10 and $100 \mu \mathrm{g} / \mathrm{ml}$. Probit analysis was used to determine $I C_{50}$. Results: In vitro antimalarial activity revealed that only three crude extracts samples from Fraxinus griffithi stem extract, Piper sulcatum leaves extract and Eucalyptus globulus stem extract had good antimalarial activity with $I C_{50}$ value of $0.33,0.20$ and $0.55 \mu \mathrm{g} / \mathrm{ml}$, respectively. Conclusions: Fraxinus griffithi stem extract, Piper sulcatum leaves extract and Eucalyptus globulus stem extract might be a good candidate for antimalarial natural product resources.
\end{abstract}

Keywords: antimalarial activity, in vitro, plasmodium falciparum, plant extracts

\begin{abstract}
Abstrak
Latar Belakang: Malaria adalah penyakit yang tergolong penting yang pengendaliannya bergantung pada kemoterapi yang spesifik, dan kondisinya menjadi lebih sulit dengan adanya resistensi Plasmodium falciparum terhadap obat antimalaria yang tersedia. Kondisi ini memicu kebutuhan terhadap alternatif terapi antimalaria. Tujuan: Tujuan dari penelitian ini adalah untuk menentukan kandidat antimalaria baru dari beberapa tanaman Indonesia yang dikoleksi dari Hutan Raya Cangar, Batu-Malang, Jawa Timur. Metode: Sebelas sampel dari ekstrak daun dan batang diuji pada kultur Plasmodium falciparum strain 3D7 yang dikembangkan dalam media RPMI-1640. Sampel diuji pada konsentrasi 0,$01 ; 0,1 ; 1 ; 10$ dan 100 $\mu \mathrm{g} / \mathrm{ml}$. Analisis probit digunakan untuk menentukan nilai $\mathrm{IC}_{50}$. Hasil: Uji aktivitas malaria in vitro menunjukkan bahwa terdapat tiga sampel dari ekstrak batang Fraxinus griffithi, ekstrak daun Piper sulcatum dan ekstrak batang Eucalyptus globulus mempunyai aktivitas antimalaria yang baik dengan nilai $\mathrm{IC}_{50}$ berturut-turut 0,$33 ; 0,20 ;$ dan $0,55 \mu \mathrm{g} / \mathrm{ml}$. Kesimpulan: Ekstrak batang Fraxinus griffithi, ekstrak daun Piper sulcatum dan ekstrak batang Eucalyptus globulus bisa menjadi kandidat yang baik sebagai sumber bahan obat antimalaria.
\end{abstract}

Kata kunci: aktivitas antimalaria, in vitro, plasmodium falciparum, ekstrak tanaman 


\section{PENDAHULUAN}

Di Indonesia, kasus malaria menjadi penyebab kematian nomor tiga di beberapa daerah endemis (Azlin, 2003). Obat antimalaria yang tersedia di Indonesia terbatas pada klorokuin, sulfadoksin-pirimetamin, kina, primakuin, dan beberapa antibiotika yang bersifat antimalaria. Pemerintah telah menetapkan pilihan pertama untuk mengatasi kasus malaria tanpa komplikasi adalah klorokuin. Penggunaan obat yang terdaftar sebagai antimalaria sudah diatur dan dibakukan oleh Departemen Kesehatan sesuai dengan daerah dan sensitivitas Plasmodium falciparum terhadap obat antimalaria. Pembatasan penggunaan obat tersebut berguna untuk menekan perkembangan kasus resistensi terhadap obat antimalaria lain (Harijanto, 2000).

Walaupun demikian, resistensi terhadap obat malaria telah menyebar luas. Resistensi dari $P$. falciparum terhadap obat antimalaria mulanya meningkat di Kamerun (Mbacham et al., 2004). Di Asia Tenggara, strain $P$. falciparum mungkin telah resisten terhadap hampir semua obat konvensial. Resistensi ini dapat disebabkan oleh kemampuan dari Plasmodium untuk menyesuaikan diri terhadap pemberian obat antimalaria (Knell, 1991). Dampak dari resistensi ini adalah kegagalan terapi. Hal ini membuat kebutuhan obat antimalaria yang lebih efektif menjadi sangat penting (Schwikkard dan Van Heerden, 2006).

Wilayah Indonesia sesungguhnya memiliki keanekaragaman jenis tumbuhan paling kaya di dunia. Dari sekitar 40.000 spesies flora yang tumbuh di dunia, Indonesia memiliki 30.000 spesies tumbuhan dan sekitar 940 spesies tumbuhan dikenal berkhasiat obat. Spesies tumbuhan yang berkhasiat obat tersebut diperkirakan meliputi 90\% dari jumlah tumbuhan obat yang beredar di Asia (Muhlisah, 1999). Bangsa Indonesia telah lama mengenal dan menggunakan tanaman berkhasiat obat sebagai salah satu upaya menanggulangi masalah kesehatan.

Obat herbal yang sudah terbukti memiliki aktivitas antimalaria adalah kinin yang diisolasi dari kulit batang Cinchona yang digunakan untuk sintesis klorokuin dan meflokuin. Selain itu, ada pula artemisinin yang diisolasi dari tanaman Artemisia аппиа dan terbukti berhasil digunakan sebagai antimalaria terhadap $P$. falciparum yang resisten klorokuin (Schwikkard dan Van Heerden, 2006). А. аппиа mempunyai kandungan kimia berupa artemisinin yaitu sesquiterpen lakton yang aktif sebagai antimalaria (Price et al., 1996). Sedangkan Chincona mengandung alkaloid seperti kuinin, kuinidin, epikuinin, epikuinidin, cinchonidin, cinchonin, epicinchonidin, dan epicinchonin. Efektivitas dari kuinin dan artemisinin sebagai antimalaria memotivasi para peneliti untuk mengeksplorasi tanaman lain sebagai obat antimalaria yang efektif (Mishra et al., 2009).

Penelitian pada familia Meliaceae, yaitu spesies Azadirachta indica menunjukkan bahwa ekstrak $A$. indica dapat menghambat pertumbuhan $P$. falciparum. Ekstrak tersebut mengandung diterpenoid, triterpenoid, protein, karbohidrat, polifenol, flavonoid, dihidrokalkon, koumarin, dan tanin (Biswas, 2002). Nilai $\mathrm{IC}_{50} A$. indica adalah sebesar 0,72-3,11 g/mL (Bray, 2006). Keanekaragaman hayati lain, spesies Morinda dari familia Rubiaceae. Ekstrak tanaman ini mengandung senyawa alkaloid, saponin, antrakuinon, terpen, dan flavonoid (Awe dan Makinde, 1998). Penelitian pada familia Piperaceae dilakukan pada daun tanaman Piper unbellatum yang mengandung flavonoid, alkaloid, saponin, terpen, derivat asam amino, xanthon, antrakuinon, striknin, minyak, dan saponin. Pada penelitian ini dilaporkan bahwa ekstrak memiliki aktivitas moderat antimalaria pada $P$. falciparum dengan nilai $\mathrm{IC}_{50}$ sebesar $40 \mathrm{~g} / \mathrm{mL}$ (Bidla et al., 2004). Familia lain yang juga sudah banyak diteliti adalah familia Acanthaceae yaitu tanaman sambiloto atau Andrographis paniculata. Senyawa andrografolida hasil isolasi sambiloto memiliki aktivitas sebagai skizontosida $\left(\mathrm{IC}_{50} 12,16 \mathrm{~g} / \mathrm{mL}\right.$ ) dan gametosida ( $\mathrm{IC}_{50} 3,61 \mathrm{~g} / \mathrm{mL}$ ) pada kultur $P$. falciparum (Widyawaruyanti, 2001).

Beberapa tanaman dari familia Myrtaceae, Myrsinaceae, Solanaceae, dan Fabaceae telah digunakan sebagai obat malaria secara tradisional. Penelitian terhadap aktifitas antimalaria beberapa tanaman dari keempat familia tersebut juga telah dilakukan sebelumnya, seperti Psidium guajava $\left(\mathrm{IC}_{50} 10-20 \mu \mathrm{g} / \mathrm{ml}\right.$ ), Syzigium aromaticum $\left(\mathrm{IC}_{50} 6,25 \mu \mathrm{g} / \mathrm{ml}\right)$ dari familia Myrtaceae, Ardisia crispa ( $\mathrm{IC}_{50} 5,9 \mu \mathrm{g} / \mathrm{ml}$ ), Maesa lanceolata $\left(\mathrm{IC}_{50} 1,6 \mu \mathrm{g} / \mathrm{ml}\right)$ dari familia Myrsinaceae, Physalis angulata ( $\left.\mathrm{IC}_{50} 1,27 \mu \mathrm{g} / \mathrm{ml}\right)$, Acnistus arborescens $\left(\mathrm{IC}_{50} 1,3 \mu \mathrm{g} / \mathrm{ml}\right)$ dari familia Solanaceae dan Glycyrrhiza glabra ( $\left.\mathrm{IC}_{50} \quad 17,5 \mu \mathrm{g} / \mathrm{ml}\right)$, Pterocarpus erinaceus $\left(\mathrm{IC}_{50} \quad 1,27 \mu \mathrm{g} / \mathrm{ml}\right)$ dari familia Fabaceae memiliki potensi aktivitas antimalaria yang baik. Aktivitas antimalaria dari tanaman-tanaman tersebut diduga disebabkan oleh adanya kandungan alkaloid, 
antrakuinon, flavonoid, dan terpenoid (Titanji et al., 2008; Katuura et al., 2007; Begum dan Goyal, 2007; Bagavan et al., 2010; Noor Rain et al., 2007; Lusakibanza et al., 2010; Garavito et al., 2006; Karou et al., 2003; Esmaeili et al., 2008).

Berdasarkan pendekatan kemotaksonomi tanaman, dipilih spesies tanaman lain dari familia Meliaceae, Rubiaceae, Piperaceae, Acanthaceae, Myrtaceae, Myrsinaceae, Solanaceae dan Fabaceae yang berdasarkan pustaka beberapa tanaman yang termasuk ke dalam suku tersebut sudah terbukti memiliki aktivitas antimalaria. Studi kemotaksonomi ialah suatu studi yang menyatakan adanya kemiripan tanda anatomi, histologi, morfologi, dan zat yang terkandung pada tanaman dalam satu familia (Hidayat, 2002).

Pada penelitian ini dipilih sebelas spesies tanaman dari delapan familia yang diambil dari kawasan Hutan Raya Cangar, Kabupaten Malang, Provinsi Jawa Timur yaitu spesies dari familia Meliaceae (1) Fraxinus griffithi, familia Rubiaceae spesies (2) Psychotria sp., spesies dari familia Piperaceae (3) Piper sulcatum, spesies dari familia Acanthaceae (4) Strophacantus membranifolius, (5) Strobilanthes involucrata, dan (6) Gompostemma javanicum, species dari familia Myrtaceae (7) Eucalyptus globulus, (8) Acmena acuminatissima, species dari familia Myrsinaceae (9) Ardisia sp., species dari familia Solanaceae (10) Cestrum calysimum, species dari familia Fabaceae (11) Calliandra portoricensis. Ekstrak dari sebelas tanaman tersebut telah diuji aktivitas antimalarianya terhadap kultur Plasmodium falciparum strain 3D7 untuk menentukan kandidat antimalaria yang potensial.

\section{BAHAN DAN METODE}

\section{Bahan tanaman}

Bahan tanaman yang digunakan pada penelitian ini adalah batang Fraxinus griffithi, daun Psychotria sp., daun Piper sulcatum, herba Strophacantus membranifolius dan Strobilanthes involucrata, batang Gompostemma javanicum, batang Eucalyptus globulus, daun Acmena acuminatissima, daun Ardisia sp., batang Cestrum calysinum, dan daun Calliandra portoricensis yang diambil dari Hutan Raya Cangar, Kabupaten Malang, Provinsi Jawa Timur pada tanggal 3 April 2010. Determinasi terhadap tanaman telah dilakukan di Kebun Raya Purwodadi - LIPI, Pasuruan Malang.
Parasit yang digunakan untuk uji in vitro adalah biakan P. falciparum strain 3D7 yang sensitif klorokuin dan dikembangkan di Fakultas Farmasi Universitas Airlangga, Surabaya, Jawa Timur. Kultur dibiakkan berdasarkan metode Trager dan Jensen (1976) yang telah dimodifikasi.

\section{Bahan lain untuk uji antimalaria secara in vitro}

Bahan yang digunakan untuk membuat medium pembiakan $P$. falciparum dan larutan uji in vitro adalah : Aquadest steril, RPMI-1640, HEPES buffer, Na Bikarbonat, Hipoxanthine, Gentamisin, Serum dan eritrosit manusia yang diperoleh dari Bank darah (PMI), Minyak imersi, ACD: Asam sitrat, trisodium sitrat, Dekstrosa, Pewarna Giemsa, Dapar fosfat : $\mathrm{Na}_{2} \mathrm{HPO} 4$ dan $\mathrm{NaH}_{2} \mathrm{PO}_{4}$, DMSO, Alkohol $70 \%$.

\section{Ekstraksi}

Ekstraksi dilakukan dengan metode ultrasonik (UaE, Ultrasonic assisted extraction). Sebanyak 10 gram serbuk simplisia diekstraksi menggunakan pelarut etanol 80\%. Serbuk simplisia direndam dalam pelarut dan diultrasonik, setiap 2 menit ekstrak diaduk, kemudian diultrasonik kembali, diulangi sebanyak tiga kali kemudian disaring. Selanjutnya dilakukan pemekatan ekstrak menggunakan rotary evaporator. Ekstrak pekat dikeringkan di dalam oven dengan suhu $40^{\circ} \mathrm{C}$.

\section{Uji aktivitas antimalaria in vitro}

Pada uji aktivitas in vitro digunakan Plasmodium falciparum strain 3D7 yang sensitif terhadap klorokuin. Secara prinsip uji aktivitas dilakukan dengan cara berikut: bahan uji (10 mg ekstrak etanol $80 \%$ ) dilarutkan dalam $100 \mu \mathrm{l}$ pelarut DMSO. Dilakukan serial pengenceran sampai diperoleh konsentrasi akhir sebesar 0,$01 ; 0,1 ; 1 ; 10$ dan $100 \mu \mathrm{g} / \mathrm{ml}$ (kultur dibuat duplo). Kemudian ditambahkan $500 \mu$ l suspensi parasit dengan kadar parasitemia $1 \%$ dan hematokrit $5 \%$ dan diinkubasi selama 48 jam pada suhu $37^{\circ} \mathrm{C}$. Setelah inkubasi, dibuat sediaan lapisan darah tipis dengan pewarnaan giemsa $20 \%$. Selanjutnya dihitung persentase parasitemia dan persentase hambatan pertumbuhan $P$. falciparum dengan menghitung jumlah eritrosit yang terinfeksi setiap 1000 eritrosit di bawah mikroskop. Persen pertumbuhan didapatkan dengan menggunakan rumus sebagai berikut:

$$
\% \text { Pertumbuhan }=\% \text { Parasitemia }-D 0
$$


Keterangan:

$$
\mathrm{D} 0=\% \text { pertumbuhan pada jam ke- } 0
$$

Rumus untuk perhitungan \% penghambatan adalah sebagai berikut:

$$
\% \text { Penghambatan }=100 \%-\left(\frac{X u}{X k} \times 100 \%\right)
$$

Keterangan:

$$
\begin{aligned}
& \mathrm{Xu}=\% \text { pertumbuhan pada larutan uji } \\
& \mathrm{Xk}=\% \text { pertumbuhan pada kontrol negatif }
\end{aligned}
$$

\section{Analisis data}

Berdasarkan data persen penghambatan rata-rata dilakukan analisis antara dosis terhadap persen penghambatan rata-rata dengan menggunakan analisis probit $\log$ untuk mengetahui nilai $\mathrm{IC}_{50}$ atau konsentrasi bahan uji yang dapat menghambat pertumbuhan parasit sebanyak $50 \%$.

\section{HASIL DAN PEMBAHASAN}

Penelitian ini dilakukan untuk mengetahui aktivitas antimalaria ekstrak etanol $80 \%$ dari sebelas spesies tanaman dari delapan familia yang didapatkan dari Hutan Raya Cangar, Batu-Malang, Jawa Timur. Pemilihan tanaman yang digunakan didasarkan pada pendekatan kemotaksonomi tanaman. Beberapa penelitian melaporkan tanaman dari familia yang sama dapat memiliki aktivitas yang sama karena kandungan kimia pada tanaman dari satu familia tidak jauh berbeda. Pada uji aktivitas antimalaria terhadap sebelas spesies tanaman tersebut dilakukan dalam bentuk ekstrak etanol $80 \%$ karena etanol $80 \%$ dapat melarutkan alkaloid bentuk garam, flavonoid, minyak atsiri, saponin, tanin, dan polifenol sehingga kandungan kimia dari tanaman dapat terekstraksi dengan baik (Voight, 1994). Senyawa kimia seperti alkaloid, flavonoid, saponin, tanin, polifenol, dan minyak atsiri sudah terbukti memiliki aktivitas antimalaria.

Penelitian aktivitas antimalaria ekstrak tanaman tersebut di atas dilakukan terhadap $P$. falciparum secara in vitro. Uji aktivitas in vitro dengan $P$. falciparum dilakukan sebagai uji pendahuluan untuk mengevaluasi bahan alam hayati yang diduga memiliki aktivitas antimalaria. Untuk skrining ekstrak dari tanaman yang digunakan untuk pengobatan tradisional, uji in vitro menawarkan keuntungan karena dapat menggunakan $P$. falciparum, penyebab malaria pada manusia yang memiliki beberapa strain yang resisten terhadap banyak obat antimalaria, sebagai parasit uji (Phillipson, 1991). Hasil uji aktivitas antimalaria in vitro dapat dilihat pada

\begin{tabular}{|c|c|c|c|c|c|c|}
\hline \multirow[t]{2}{*}{ Ekstrak } & \multicolumn{5}{|c|}{$(\mu \mathrm{g} / \mathrm{mL})$} & \multirow[t]{2}{*}{$\mathrm{IC}_{50}(\mu \mathrm{g} / \mathrm{mL})$} \\
\hline & 100 & 10 & 1 & 0,1 & 0,01 & \\
\hline Batang $F$. griffithi & $\mathbf{9 2 , 8 2}$ & 76,65 & 55,84 & 40,48 & 22,44 & $\mathbf{0 , 3 3}$ \\
\hline Daun Psychotria sp. & 46,00 & 39,34 & 34,97 & 28,15 & 22,34 & 381,64 \\
\hline Daun $P$. sulcatum & 92,29 & $\mathbf{7 1 , 8 3}$ & 64,05 & 46,20 & 26,63 & $\mathbf{0 , 2 0}$ \\
\hline Herba S. membranifolius & 82,53 & 55,77 & 32,80 & 20,45 & 14,27 & 3,49 \\
\hline Herba $S$. involucrata & 90,35 & 58,50 & 42,90 & 31,04 & 17,90 & 1,26 \\
\hline Batang G. javanicum & 83,48 & 64,02 & 46,09 & 28,18 & 15,71 & 1,45 \\
\hline Batang E. globulus & 100,00 & $\mathbf{9 3 , 7 5}$ & 36,51 & 29,55 & 14,06 & $\mathbf{0 , 5 5}$ \\
\hline Daun A. acuminatissima & 95,55 & 84,72 & 20,74 & 14,31 & 5,30 & 1,85 \\
\hline Daun Ardisia sp. & 100,00 & 82,22 & 28,99 & 15,46 & 11,98 & 5,06 \\
\hline Batang C. calysinum & 46,20 & 28,38 & 25,25 & 19,55 & 8,33 & 343,94 \\
\hline Daun C. portoricensis & 53,29 & 35,12 & 30,10 & 24,19 & 8,25 & 67,91 \\
\hline
\end{tabular}
Tabel 1 dan Tabel 2 berikut ini.

Tabel. 1. Persen Penghambatan Ekstrak dan Hasil Analisis Probit terhadap P.falciparum In Vitro

$$
\% \text { Hambatan rata-rata pada konsentrasi yang diuji }
$$

Tabel. 2. Pengelompokan Kekuatan Aktivitas Ekstrak terhadap P. falciparum 3D7 In Vitro

Ekstrak Nilai $\mathrm{IC}_{50}(\mu \mathrm{g} / \mathrm{mL}) \quad$ Aktivitas Antimalaria




\begin{tabular}{lcc}
\hline Batang $\boldsymbol{F}$. griffithi & $\mathbf{0 , 3 3}$ & Baik \\
Daun Psychotria sp. & 381,64 & Tidak aktif \\
Daun $\boldsymbol{P}$. sulcatum & $\mathbf{0 , 2 0}$ & Baik \\
Herba . membranifolius & 3,49 & Moderat \\
Herba $S$. involucrata & 1,26 & Moderat \\
Batang G. javanicum & 1,45 & Moderat \\
Batang E. globulus & $\mathbf{0 , 5 5}$ & Baik \\
Daun A. acuminatissima & 1,85 & Moderat \\
Daun Ardisia sp. & 5,06 & Moderat \\
Batang C. calysinum & 343,94 & Tidak aktif \\
Daun C. portoricensis & 67,91 & Sangat lemah \\
\hline
\end{tabular}

Berdasarkan Rosoanaivo et al., (2004) ekstrak dikatakan memiliki aktivitas yang sangat baik sebagai antimalaria apabila nilai $\mathrm{IC}_{50}<0,1 \mu \mathrm{g} / \mathrm{ml}$, aktivitas antimalaria baik bila $\mathrm{IC}_{50} \quad 0,1-1,0 \mu \mathrm{g} / \mathrm{ml}$, aktivitas antimalaria moderat bila $\mathrm{IC}_{50} 1,1-10 \mu \mathrm{g} / \mathrm{ml}$, lemah bila $\mathrm{IC}_{50} 11-25 \mu \mathrm{g} / \mathrm{ml}$, sangat lemah bila $\mathrm{IC}_{50} 26-50 \mu \mathrm{g} / \mathrm{ml}$ dan tidak aktif bila $\mathrm{IC}_{50}>100 \mu \mathrm{g} / \mathrm{ml}$.

Uji aktivitas antimalaria in vitro menunjukkan bahwa terdapat tiga sampel dari ekstrak batang Eucalyptus globules (Myrtaceae), ekstrak batang Fraxinus griffithi (Meliaceae) dan ekstrak daun Piper sulcatum (Piperaceae) mempunyai aktivitas antimalaria yang baik dengan nilai $\mathrm{IC}_{50}$ berturut-turut 0,$55 ; 0,33$ dan $0,20 \mu \mathrm{g} / \mathrm{ml}$. Familia Myrtaceae, Meliaceae dan Piperaceae banyak mengandung senyawa terpenoid dan flavonoid yang kemungkinan memberikan aktivitas antimalaria. Hal ini didukung dengan adanya laporan bahwa senyawa golongan alkaloid, terpenoid dan flavonoid mayoritas berperan sebagai antimalaria (Saxena et al., 2003; Bero et al., 2009). Dilaporkan pula bahwa familia Caesalpiniaceae, Asteraceae, Leguminoceae, Moraceae, Piperaceae dan Meliaceae digolongkan sebagai familia yang banyak mengandung senyawa antimalaria. Banyak senyawa yang diisolasi dari tanaman telah terbukti aktif sebagai antimalaria. Senyawa fenolik yang diisolasi dari tanaman Calycolpus warscewiczianus familia Myrtaceae aktif menghambat pertumbuhan P.falciparum strain W2 dengan nilai $\mathrm{IC}_{50}$ 14,5 $\mu \mathrm{M}$. Begitu juga dengan senyawa-senyawa fenolik dan terpenoid dari familia Meliaceae dan Piperaceae yang dilaporkan mempunyai aktivitas antimalaria yang baik dalam menghambat pertumbuhan beberapa strain P.falciparum (Bero et al., 2009). Berdasarkan nilai $\mathrm{IC}_{50}$ dari ketiga ekstrak tersebut, Piper sulcatum dari familia Piperaceae mempunyai aktivitas yang paling baik. Familia Piperaceae juga diketahui mengandung banyak minyak atsiri dan alkaloid (Park et al., 2002). Kemungkinan kandungan senyawa tersebut juga berperan dalam meningkatkan aktivitasnya sebagai antimalaria.

Kristanti et al., (2008) menyatakan bahwa tanaman dari takson yang sama mempunyai hubungan kekerabatan kandungan senyawa terkandung yang erat, terutama pada tingkat familia, genus, dan species. Berdasarkan hasil yang didapat, tanaman dari famili Myrtaceae, Meliaceae dan Piperaceae memiliki aktivitas antimalaria yang baik. Hal ini sesuai dengan pendekatan kemotaksonomi yang digunakan yaitu bahwa pada ketiga tanaman dari tiga familia tersebut terdapat kandungan senyawa yang mirip dengan tanaman lain dari familia yang sama yang sebelumnya telah dilaporkan memiliki aktivitas antimalaria.

\section{KESIMPULAN}

Ekstrak batang Eucalyptus globulus, ekstrak batang Fraxinus griffithi dan ekstrak daun Piper sulcatum merupakan kandidat sumber bahan obat antimalaria yang sangat potensial.

\section{UCAPAN TERIMA KASIH}

Riset ini menerima bantuan dana dari Project Grant Fakultas Farmasi Universitas Airlangga Tahun 2011.

\section{DAFTAR PUSTAKA}

Awe SO, Makinde JM. 1998. Evaluation of sensitivity of Plasmodium falciparum to Morinda lucida leaf extract sample using rabbit in vitro microtest technique. Indian J Pharmacol. 30(1):51-53.

Azlin E. 2003. Uji klinis acak tersamar ganda gabungan sulfadoksin-pirimetamin dengan klorokuin pada malaria. Laporan penelitian. Bagian Ilmu Kesehatan Anak Fakultas Kedokteran. Universitas Sumatera Utara. Cited on: www.digital.usu.lib

Bagavan A, Rahuman A, Kamaraj C, Kaushik NK, Mohanakrishnan D. 2010. Antiplasmodial activity of botanical extract against Plasmodium falciparum. Parasitology Research. Vol 108 Number 1 pp 15-22. 
Begum AD, Goyal M. 2007. Research and Medicinal Potential of Genus Cestrum (Solanaceae). Pharmacognosy Reviews. Vol 1 issue 2.

Bero J, Frederich M, Quetin-Leclercq J. 2009. Antimalarial compounds isolated from plants used in traditional medicine. Journal of Pharmacy and Pharmacology. 61:1401-1433.

Bidla G, Titanji VPK, Jako B, Ghazali GE, Bolad A, Berzins K. 2004. Antiplasmodial activity of seven plants used in African folk medicine. Indian $J$ Pharmacol 36:245-246.

Biswas K, 2002. Biological activities and medicinal properties of neem (Azadirachta indica). Current Science. vol 82, No.11:1336-1345.

Esmaeili S, Naghibi F, Mosaddegh M, Sahranavard S, Ghafari S, Abdullah NR. 2008. Screening of antiplasmodial properties among some traditionally used Iranian plants. Journal of Ethnopharmacology. Vol 121, pp 400-404.

Garavito G, Rinc'on J, Arteaga L, Hata Y, Bourdy G, Gimenez A, et al. 2006. Antimalarial activity of some Colombian medicinal plants. Journal of Ethnopharmacology. Vol 107 pp 460-462.

Harijanto PN. 2000. Malaria : Epidemiologi, Patogenesis, Manifestasi Klinis, dan Penanganan. Jakarta: Penerbit Buku Kedokteran EGC.

Hidayat MA. 2002. Uji aktivitas antikanker ekstrak heksana daun Eupatorium triplinerve Vahl terhadap kultur sel myeloma. Jurnal Ilmu Dasar. Vol 3 (2):92.

Katuura E, Waako P, Tabuti JRS, Bukenya-Ziraba R, Ogwal-Okeng J. 2007. Antiplasmodial Activity of Extracts of Selected Medicinal Plants Used by Local Communities in Western Uganda for Treatment of Malaria. African Journal of Ecology. Vol. 45 (3):94-98.

Karou D, Dicko MH, Sanon S, Simpore J, Traore AS. 2003. Antimalarial activity of Sida acuta Burm. f. (Malvaceae) and Pterocarpus erinaceus Poir. (Fabaceae). Journal of Ethnopharmacology. vol. 89 (2-3):291-294.

Knell AJ. 1991. Malaria. New York:Oxford University Press, pp 29-30.

Kristanti AN, Aminah NS, Tanjung M, Kurniadi B. 2008. Buku Ajar Fitokimia. Surabaya : Airlangga University Press.

Lusakibanza M, Mesia G, Tona G, Karemere S, Lukuka A, Tits M, et al. 2010. In vitro and in vivo antimalarial and cytotoxic activity of five plants used in Congolese traditional medicine. Journal of Ethnopharmacology. vol. 129 (3):398-402.

Mbacham W, Roper C, Targett G, Grenwood B. 2004. Gates malaria partnership annual report. Antimalarial drug resistance in Cameroon: Therapeutic efficacy and biological marker resistance, $\mathrm{p} 13$.
Mishra K. Dash AP, Swain BK, Dey N. 2009. Antimalarial activities of Andrographis paniculata and Hedyotis corymbosa extract and their combination with curcumin. Malaria journal. 8:26.

Muhlisah FI, 1999. Тети-temuan dan empon-empon, budi daya dan manfaatnya. Yogyakarta. Kanisius.

Noor Rain A, Khozirah S, Mohd Ridzuan MAR, Ong BK, Rohaya C, Rosilawati M, et al., 2007. Antiplasmodial properties of some Malaysian medicinal plants. Tropical Biomedicine. Vol 24 Issue (1) pp 29-35.

Park IK, Lee SG, Shin SC, Pak JD, Ahn YJ. 2002. Larvicidal activity of isobuthylamides identified in Piper nigrum fruits against three mosquito species, J Agric Food Chem. 50(7):1866-1870.

Phillipson JD. 1991. Assays for Antimalarial and Amoebicidal Activities. Methods In Plant Biochemistry. Vol. 6, pp 135-141.

Price RN, Nosten F, Luxemburger C. 1996. Effects of artemisinin derivatives on malaria transmissibility. Lancet. 347:1654-1655.

Rasoanaivo P, Eric D, Suzanne R, Frappier F. 2004. Traditional Medicinal Plants and Malaria: Guidelines for the Nonclinical Evaluation of the Efficacy of Traditional Antimalarials, CRC Press, p. 266.

Saxena S, Pant N, Jain DC, Bhakuni RS. 2003. Antimalarial Agents from Plant Sources. Current Science. Vol 8 (9):1314-1329.

Schwikkard S, Van Heerden FR. 2006. Antimalarial activity of plant metabolites. Nat Prod Rep 19:675-692.

Titanji VPK, Zofou D, Ngemenya MN. 2008. The antimalarial potential of medicinal plants used for the treatment of malaria in Cameroonian folk medicine. African Journal of Traditional, Complementary and Alternative Medicine. Vol. 5(3):302-321.

Trager W, Jensen WB. 1976. Human Malaria Parasites in Continuous Culture. Science.193:673-675.

Voight R. 1994. Buku Pelajaran Teknologi Farmasi, Edisi Kelima, Yogyakarta : Penerbit Gadjah Mada University Press.

Widyawaruyanti A. 2001. Uji aktivitas antimalaria dari senyawa diterpen laktona hasil isolasi Andrographis paniculata Nees. Laporan Penelitian Project Grant-QUE, Fakultas Farmasi, Universitas Airlangga. 